\title{
INITIAL RESULTS OF A DIFFERENTIATE PROGRAM OF TEACHERS CONTINUING FORMATION IN BRAZIL: THE PDE/PARANA
}

\author{
Romilda Teodora Ens, Gisele Rietow Bertotti \\ PUCPR, Curitiba, Brazil \\ E-mail: romilda.ens@gmail.com, giselertw@gmail.com \\ Rudimar Gomes Bertotti \\ UFPR, Curitiba, Brazil \\ E-mail: rudigbertotti@gmail.com
}

\begin{abstract}
This research presents an innovative practice of continuing formation, which shows a connection between the public school and higher education, the Program of Educational Development of Parana/ Brazil (PDE-PR) and its relation to the results of IDEB (Index of Basic Education Development) in public state schools of Curitiba. This research aims to analyse the relation between the teacher's formation and the index of development/knowledge presented by their students in the large scale exam applied in Brazil, based on a qualitative approach through a comparison among some factor based on the number of schools which had participants in PDE-PR, established goals and results obtained in the IDEB of 2007 and 2009 by students of the $9^{\text {th }}$ grade. The results showed that 18 of 61 schools which had participants did not reach the established goal, but 23 presented an increase in their grade, in spite of not achieving the objective. The analyses indicate the per passed routes are opposed to the effectiveness of democratic spaces in the schools. Thus, at the same they emphasize the appreciation of the teacher in the legal documents, establish the formative process as the only way to access the last level of the teaching career, emphasizing mainly work time, in the entrance exam to the program, and seeking to achieve the established goals to improve the public schools which substantiate in the IDEB's grade.
\end{abstract}

Key words: $I D E B, P D E$, teacher's continuing formation, large scale exam.

\section{Introduction}

Considering the political texts which regulate the continued formation of Program of Educational Development of Parana/ Brazil (PDE-PR) for elementary school teachers and its relationship with the grade obtained in Index of Basic Education Development (IDEB), specifically in the state of Paraná, was the challenge we set ourselves, taking the official texts emanating from educational institutions to understand the official policy that sets expectations and guidelines for in-service teacher training and the evaluation of basic school, in Paraná. The first, policy of the state government and the second, federal government policy, both focused on education. The two programs, which we refer to emerge from the demands of changes in the role of the school in the context of the contemporary school involves enormous diversity and complexity, reflections of contemporary society in constant transformation. "Transformations, which affect not only the organization of the school, but also the forms of relationship, of the teacher's work, and the way students and teachers learn", as indicated Ens \& Gisi (2011, p. 39). 
Romilda Teodora ENS, Gisele Rietow BERTOTTI, Rudimar Gomes BERTOTTI. Initial Results of a Differentiate Program of Teachers Continuing Formation in Brazil: The PDE/Parana

EMMS

OF EDUCATION

IN THE $21^{\text {st }}$ CENTURY

Volume 60, 2014

Volume 60, 2014

These aspects indicate a change in the role of schools to society, from an integrative institution in economic, social, political and cultural terms, to the formative agency of manpower to the labor market, aiming to seek the development of human capital in individual terms and encouraging competition between nations and individuals (Foucault, 2008; Gentili, 2004).

This condition, known as 'school crisis' was due to its inability to promote the much desired social mobility seen that during the 1970s and throughout the 1980s, there were significant changes in the economic structure of the capitalist world, due to the oil crisis. The consequences of these changes were the perpetuation of inequality, unemployment, demonstrating that education can cope with modernization and poverty and to ensure greater access to education does not necessarily imply economic development (Apple \& Gandin, 2011).

The influences of neoliberalism in education could be observed more clearly from the 1990s, when it perpetuated the devaluation of teaching, the academic difficulties were attributed to the teachers, making it natural and inherent in the educational process and public funding was organized into three axes: funding, evaluation and monitoring of activity, transferring characteristics of the market to the educational system (Silva, 2011).

The emphasis on monitoring of education through testing has shown tendencies to blame only professional teachers by the results obtained in the educational process, assuming classificatory nature, stimulating competition and distributing resources to institutions that get better rankings (Oliveira, 2009). In this context, the National Institute for Educational Studies and Research (INEP), in Brazil, created the IDEB (Index of Basic Education Development), continuing the policy of large scale evaluation already ongoing in the higher education.

It is known that several factors influence the score that students get into qualifying tests and that neither teachers nor students can be fully liable for their performance (Silva, 2011). However, it is clear that the political speeches blame the teachers for the quality of school. It is in this correlation of forces that this comparative analysis aims to examine the relationship between the teacher's formation and the index of student knowledge / development, obtained in IDEB in 2007 and 2009 by students of the $9^{\text {th }}$ grade of elementary school.

To this end, a research of schools in Curitiba / PR who had teachers who participated in the continuing education process was performed. Then, in the selected schools, established goals and the results obtained by students in the 9th grade for the IDEB 2007 and 2009 were identified. Initially, , checking the occurrence or not of increasing grade, while analyzing if the goals set by the school were achieved to establish the relationship between expectations and achievement of goals. After, the comparison between the teacher's formation and the index of the development of basic education was performed.

\section{Index of Basic Education Development}

In order to create an indicator of educational development, which takes into account both performance information on issues of school exams as school flow, was created by the National Institute for Educational Studies and Research, in 2007, the Index of Basic Education Development:

IDEB (Fernandes, 2007). This index measures and updated every two years, with the goal that by 2021 the average Brazilian municipal and state schools arrive at six, which, according to the MEC (Ministry of education), corresponds to education granted in developed countries.

The IDEB includes information obtained from the Brazil test, part of the National Education Assessment System (SAEB). It consists of two assessments: National Assessment of Basic Education (ANEB) and National Assessment of Educational Achievement (ANRESC), known as Brazil Test. This evaluation aims to demonstrate the performance in Portuguese language and Mathematics, and it applies to students of the 5th and 9th grades of basic education schools.

This index (IDEB) has great influence in shaping educational policies, for being considered a portrait of Brazilian education, being defined by defined by the sole paragraph of art. 
$3^{\text {rd }}$ of Decree n. 6094/2007, as "the indicator for the purpose of verifying compliance with the targets set in terms of adherence to Commitment" established by the Plan on Education for All and Commitment. In this document it has stimulated educational development by focusing on the results of tests, combating school dropout, repetition, emphasizing the integration of individuals with special needs, a stronger integration between teaching and teachers, and between school and community. Complementing, in Article $3^{\text {rd }}$ is established that "the quality of basic education will be measured objectively based on IDEB calculated and periodically released by the national institute of educational research Anisio Teixeira (INEP) [...]" (IDEB. Brazil, 2007).

In addition to determining its use for the evaluation of school performance, its importance is reiterated through a series of incentives, mainly in the form of financial and technical assistance to schools, establishing competition, known as rankings, between institutions. Incentives turn to "[...] supplementary and voluntary support for public networks basic education of Municipalities, States and Federal District granted by the union." Support which can be translated into "technical or financial assistance" (Brazil, 2007).

Due to regulations established by the institutional evaluation in Brazilian public schools, it is necessary and important to understand how the calculation is performed in IDEB, which factors are taken into account and which aspects are highlighted by the use of this practice. It is based on two components: rate of school performance (approval) and mean performance on standardized tests applied by INEP. Pass rates are obtained based on School Census (EDUCACENSO), conducted annually by INEP. The performance averages used are the Brazil Test (Idebs of schools and municipalities) and Saeb, which is a test of Portuguese and Mathematics applied nationally (in the case of Idebs state and national).

The formula of IDEB is given by:

\begin{tabular}{l}
\hline IDEBji = Nji Pji \\
\hline In which \\
\hline $\mathrm{i}=$ year of exam (Saeb and Brazil Test) and the School Census \\
\hline $\mathrm{Nji}=$ average of proficiency in Portuguese language and Mathematics, standardized for an indicator between 0 and \\
10 , the students of unit $\mathrm{j}$, obtained in particular edition of the examination at the end of the middle stage of education \\
\hline Pji = performance indicator based on the rate of approval of students of unit $\mathrm{j}$ \\
\hline Source: IDEB. Alagoas (2007).
\end{tabular}

This combination explains Fernandes (2007), seeks to "encourage schools and school systems to adopt certain 'exchange rate' between the expected proficiency of students at the end of a stage of education and the average time duration for its completion" (p. 10). In other words, students must demonstrate learning through a stipulated performance on a yearly basis, thereby seeking to reduce the rates of disapproval.

The variation of the grade occurs $0-10$, with an average 6.0 stipulated as goal 7 of the National Education Plan until the year 2021 (Law Project Brazil, 2010), aimed at reducing educational inequality. This value was chosen based on the score achieved by countries that comprise the OECD (Organization for Economic Cooperation and Development), relating data of Saeb with the PISA (Programme for International Student Assessment).

\section{Teacher Development Program - PDE- Parana}

The PDE-PR, teacher development program is "a program of continuing formation implanted as a permanent educational policy, which provides for the annual inflow of teachers from the State Public School for participation in continuing training process lasting two (2) 
Romilda Teodora ENS, Gisele Rietow BERTOTTI, Rudimar Gomes BERTOTTI. Initial Results of a Differentiate Program of Teachers Continuing Formation in Brazil: The PDE/Parana

PROBLEMS

OF EDUCATION

IN THE $21^{\text {st }}$ CENTURY

Volume 60, 2014

years, with the goal to qualitative improvement of teaching and learning in the public schools of Basic Education “(Complementary Law. Parana, 2010a).

In 2010, it became a public policy of the state government of Parana, by the complementary law n. 130 and imposed by Complementary Law N. 103/2004, with the goal of providing Continuing Education for Public Education Network Teachers of Paraná (Complementary Law. Parana, 2004).

To better understand it, it is necessary to resume historically educational policies in the state of Parana. The neoliberal assumptions influenced the educational system during the government of Jaime Lerner, 1995-2002, by entering the parameters of efficiency and rationality. This new strand meant the reduced investment and culminated in casualization of teaching by establishing practical training, based on temporary contracts and not directed to a career plan, submitting to the teacher labor market variables (Lara \& Maroneze, 2012).

These variables were used in the search for quick results and improvement of educational indicators, some continued education programs for teachers of basic education in Parana were implemented. Among them, the "University Teacher - training center of Faxinal do ceu" project, where they were offered three types of training: Seminar Update and Motivation Seminar Update Course and Specialization Courses and Extension. Counting with an approximate number of 960 participants per event, where multipliers were formed and assigned to train groups of 40 teachers who worked in the same region (Munhoz \& Kovaliczn, 2008).

On the other hand, at Requião's government (2003/2010), which stated prioritize the upgrading of teachers, we had the creation of the initial and continuing education program FOCO. Featuring seminars to the disciplines of the official curriculum, in-depth courses, study groups by areas of education. The whole process culminated in the development of the Educational Development Program - PDE in 2006 with a first class, for which 1200 vacancies were offered to teachers in the state schools of Parana.

In accordance with the "Summary Document " on the PDE-PR (2014 version), from 2003, was instituted a new policy of upgrading teachers implanting the Educational Development Program - PDE, to be developed by the Secretariat of State for Science, Technology and Higher Education, with the involvement of the public schools of Basic Education and Higher Education Institutions, seeking to integrate these levels of education.

With these objectives, the PDE-PR (Law 130/2010) proposed the following assumptions, which are flown to the present time: recognize teachers as producers of knowledge about the teaching-learning process; organization of continuous training program focused on the needs of basic education; overcoming the discontinuous and homogeneous formation model; integrate basic and higher education institutions; and create conditions within the school, for the discussion and promotion of spaces for collective construction of knowledge (Synthesis document. Parana, 2014).

About the PDE-PR, Wachowicz (2009) complements its objectives and assumptions show a public policy that seeks, besides the establishment a relationship between the teachers of basic education and higher education, to promote an incentive to research and reflection on professional practice, putting the teacher in the highest level of career promotion. Therefore, according to the author, the PDE is constituted as a didactic inversion, an active method, since it contemplates the role of the participant and with "[...] experience, collective reflection, intention in transforming analyzed professional practice, broadening the sources of knowledge for learning and commitment in teaching mediation as subjects responsible for the mediation of culture "(p. 43).

PDE-PR (Continuing Education) proposes to state school teachers, through this program, the return to academic activities in the area of initial teacher training during the PDE. The participation of the teacher is made in person, in public Universities and Colleges of the State of Paraná, and in blended form of a permanent contact with the other teachers in the state public education supported by the necessary technological support to developing of collaborative activity (Synthesis document. Parana, 2014). 
To participate in the program, the teacher must be at level two of his/her career, in classes 8-11. Shall mean the division level as the second career schooling, titling or certification, the two match specialist title, conferred those who attended lato sensu post-graduation. The classes correspond to functional units of progression obtained with the combination of criteria for evaluating performance and participation in training and / or professional qualification activities.

The program lasts two years and guarantees the right to withdrawal paid $100 \%$ in the first year of their actual workload and $25 \%$ in the second year of the program.

Thus, one can say that the PDE-PR, although it is a continuing education program, meets some of the challenges to undergraduate programs, that according to Silva (2011) are: "[...] reinvent ways of learning for students from multiple cultures; offer content involving the historically produced with new knowledge and everyday topics “(p. 327). Moreover, it has enabled the participating teacher to "propose, recreate and develop projects of high social relevance and self-sustaining; driving knowledge by print and media resources, and explain the meaning of this in life "(p. 327). Preparing to "provide knowledge for the subject in a way they can understand and recreate it in a critical and autonomous way" (p. 327).

It is worth noting that, as argued by Garcia (2008, p. 368), people live in: "[...] a time of transition in Brazilian education. [...] Moreover, in the text of the new educational discourses, we find new roles to be exercised by educators as well as renewed expectations for student performance".

Based on the issues raised, about the new teacher's assignments, there are some priorities that are focused on participation, as previously defined by the policies of training and teaching work, in other words, the teachers' participation in policy of teacher education as a professional category, and the formulation of projects that have the school and its pedagogical practice as a center. Thus, according to Gatti and Barreto's (2009) analysis, they do not engage, "do not appropriate of the principles, and do not feel encouraged to change their practice, through the construction of alternative actions, while refusing to act as mere executors of external proposals" (pp. 201-202).

The involvement of teachers becomes crucial for the development of policies that prioritize educational development in the search for an emancipatory practice, enhancing the critical skills of the student, his/her curiosity, his/her insubordination. Despite this focus on improving student should be put into practice the gnosiologic cycle in which we teach and learn existing knowledge, and the production of knowledge that does not yet exist, combined with research, demonstrates the practice required of being a teacher (Freire, 2012).

\section{Methodology of Research and Results}

To achieve the proposed objective of this research, we opted for an exploratory qualitative approach, through a comparative study, seeking the improvement of ideas or discovery, in other words, seeking greater familiarity with the research object. To this end, we conducted a survey of schools in Curitiba / PR that have teachers who participated in the process of continuing education (Table 1). 
Romilda Teodora ENS, Gisele Rietow BERTOTTI, Rudimar Gomes BERTOTTI. Initial Results of a Differentiate Program of Teachers Continuing Formation in Brazil: The PDE/Parana

PROBLEMS

OF EDUCATION

IN THE $21^{\text {st }}$ CENTURY Volume 60,2014

Table 1. Number of teachers participating in the PDE-PR 2007-2009 by study areas.

\begin{tabular}{llll}
\hline & & Participants 2007/2009 & \\
\hline & Study areas & Schools attended & $\begin{array}{l}\text { Number of schools which are evaluated } \\
\text { by IDEB (elementary - final grades) }\end{array}$ \\
\hline 1 & Biology & 8 & 6 \\
\hline 2 & Science & 10 & 7 \\
\hline 3 & Technical Subjects & 1 & 0 \\
\hline 4 & Art & 1 & 0 \\
\hline 5 & Special Education & 13 & 3 \\
\hline 6 & Physical Education & 9 & 7 \\
\hline 7 & Physics & 1 & 1 \\
\hline 8 & Geography & 13 & 8 \\
\hline 9 & School management & 13 & 7 \\
\hline 10 & History & 17 & 12 \\
\hline 11 & Foreign Language - & 10 & 6 \\
& English & & 1 \\
\hline 12 & Foreign Language - Italian & 1 & 14 \\
\hline 13 & Portuguese & 22 & 5 \\
\hline 14 & Mathematics & 9 & 16 \\
\hline 15 & Education & 23 & 3 \\
\hline 16 & Chemistry & 3 & 96 \\
\hline & TOTAL & 154 & 1619 \\
\hline
\end{tabular}

* The teacher to join the PDE chooses one of the lines of study to guide their production

In selected schools, we identified the targets for the IDEB 2007 and 2009 and the results obtained by students in the 9th grade. With respect to the stated goals and grades obtained by institutions that have teachers or educators in PDE/PR 2007 and with IDEB 2007 and 2009, we have the data shown in Table 2. 
Romilda Teodora ENS, Gisele Rietow BERTOTTI, Rudimar Gomes BERTOTTI. Initial Results of a Differentiate Program of Teachers Continuing Formation in Brazil: The PDE/Parana

Table 2. Number of participating teachers and educators for state schools in
Curitiba/PR/Brazil and IDEB $2007 / 2009$.

\begin{tabular}{|c|c|c|c|c|c|}
\hline Curitiba/PR & Participants PDE/PR - 2007 & IDEB & & IDEB & \\
\hline School & Teachers $\quad$ Educators & Goal & Grade obtained & Goal & Grade obtained \\
\hline 1 & 1 & 30 & 36 & 31 & 30 \\
\hline 2 & 4 & 36 & 41 & 38 & 35 \\
\hline 3 & 2 & 43 & 62 & 48 & 53 \\
\hline 4 & 3 & 38 & 46 & 39 & 49 \\
\hline 5 & 1 & 41 & 42 & 43 & 37 \\
\hline 6 & 1 & 28 & 33 & 30 & 30 \\
\hline 7 & 1 & 0 & 41 & 42 & 46 \\
\hline 8 & 1 & 40 & 46 & 41 & 45 \\
\hline 9 & 1 & 34 & 38 & 35 & 42 \\
\hline 10 & 1 & 40 & 36 & 41 & 37 \\
\hline 11 & 2 & 46 & 49 & 47 & 51 \\
\hline 12 & 1 & 32 & 29 & 33 & 29 \\
\hline 13 & 1 & 25 & 39 & 27 & 28 \\
\hline 14 & 2 & 49 & 52 & 51 & 51 \\
\hline 15 & 2 & 45 & 56 & 47 & 50 \\
\hline 16 & 1 & 49 & 45 & 50 & 51 \\
\hline 17 & 1 & 34 & 41 & 35 & 42 \\
\hline 18 & 1 & 36 & 39 & 48 & 44 \\
\hline 19 & 2 & 37 & 36 & 41 & 40 \\
\hline 20 & 1 & 39 & 41 & 38 & 41 \\
\hline 21 & 1 & 33 & 36 & 34 & 40 \\
\hline 22 & 2 & 30 & 33 & 33 & 37 \\
\hline 23 & 1 & 30 & 35 & 35 & 30 \\
\hline 24 & 1 & 34 & 38 & 37 & 35 \\
\hline 25 & 1 & 37 & 46 & 39 & 45 \\
\hline 26 & 1 & 30 & 30 & 32 & 40 \\
\hline 27 & 2 & 36 & 36 & 38 & 40 \\
\hline 28 & 1 & 35 & 42 & 37 & 38 \\
\hline 29 & 2 & 31 & 41 & 33 & 46 \\
\hline 30 & 1 & 40 & 41 & 42 & 43 \\
\hline 31 & 1 & 29 & 32 & 31 & 37 \\
\hline 32 & 1 & 38 & 38 & 40 & 44 \\
\hline 33 & 1 & 39 & 44 & 41 & 41 \\
\hline 34 & 1 & 34 & 43 & 36 & 47 \\
\hline 35 & 1 & 39 & 46 & 41 & 45 \\
\hline 36 & 1 & 34 & 29 & 36 & 37 \\
\hline 37 & 1 & 35 & 41 & 37 & 34 \\
\hline 38 & 1 & 34 & 40 & 35 & 35 \\
\hline 39 & 1 & 48 & 46 & 46 & 49 \\
\hline 40 & 1 & 35 & 33 & 37 & 41 \\
\hline 41 & 2 & 36 & 41 & 37 & 54 \\
\hline 42 & 1 & 27 & 40 & 29 & 40 \\
\hline 43 & 1 & 30 & 39 & 32 & 40 \\
\hline 44 & 1 & 42 & 48 & 43 & 48 \\
\hline 45 & 8 & 0 & 0 & 0 & 63 \\
\hline 46 & 1 & 27 & 45 & 29 & 51 \\
\hline 47 & 3 & 33 & 47 & 34 & 56 \\
\hline 48 & 1 & 36 & 42 & 37 & 37 \\
\hline 49 & 1 & 40 & 44 & 42 & 42 \\
\hline 50 & 1 & 0 & 36 & 37 & 44 \\
\hline 51 & 1 & 33 & 38 & 35 & 33 \\
\hline 52 & 1 & 43 & 46 & 44 & 39 \\
\hline 53 & 1 & 44 & 45 & 46 & 0 \\
\hline 54 & 1 & 37 & 43 & 38 & 35 \\
\hline 55 & 3 & 33 & 42 & 35 & 42 \\
\hline 56 & 1 & 39 & 42 & 41 & 46 \\
\hline 57 & 1 & 25 & 28 & 28 & 30 \\
\hline 58 & 3 & 37 & 38 & 39 & 44 \\
\hline 59 & 3 & 37 & 32 & 38 & 31 \\
\hline \multirow[t]{2}{*}{60} & 1 & 33 & 35 & 34 & 38 \\
\hline & 1 & 35 & 39 & 37 & 36 \\
\hline Total & 80 & & & & \\
\hline
\end{tabular}

Source: SEED / PR (2012) and IDEB's website (2014) 
Romilda Teodora ENS, Gisele Rietow BERTOTTI, Rudimar Gomes BERTOTTI. Initial Results of a Differentiate Program of Teachers Continuing Formation in Brazil: The PDE/Parana

PROBLEMS

OF EDUCATION

IN THE $21^{\text {st }}$ CENTURY

Volume 60, 2014

Surveys show that, from the 1200 vacancies offered to practicing teachers in the state schools of Paraná, in 1135 completed their studies in 2009, started in 2007. From these, ninetysix were filled by teachers and educators of Curitiba, while the others were filled by teachers who work in different learning modalities (Center for distance education (CEAD), Department of education SEED, Center of education for youth and adults (CEEBJA) teachers union and schools of special education and vocational), with a percentage of $13.5 \%$ of participants in the state capital, guided by teachers of UFPR (Federal University of Parana) UTFPR (Technological University of Parana). The region of Curitiba was selected for its location and for hosting the Secretaries of State and Government, and consequently the centre of the decisions concerning educational policies. It is important to mention that the teachers returned to the schools in 2008 and developed projects according the teacher's formation program proposal based on the reality they faced at the schools and guided by the professors of Higher Level Institutions of Parana.

We note that participation in the first year of the PDE-PR program was limited, as most had only one participant in the teaching program. This small number is due to the fact that teachers need to fulfill some requirements involving years of service to reach the established class and training at post-graduate level, lato or stricto sensu. The school, which had the highest number of participating teachers had eight participants, explained this number because it is the institution with the highest number of teachers in Curitiba.

Establishing the relationship between the number of participants and the proposed goals and achieved or not, one can say that the sixty-one public schools in Curitiba / PR who had teachers participating in the PDE-PR program, thirty-nine achieved the goals the IDEB (Figure 1).

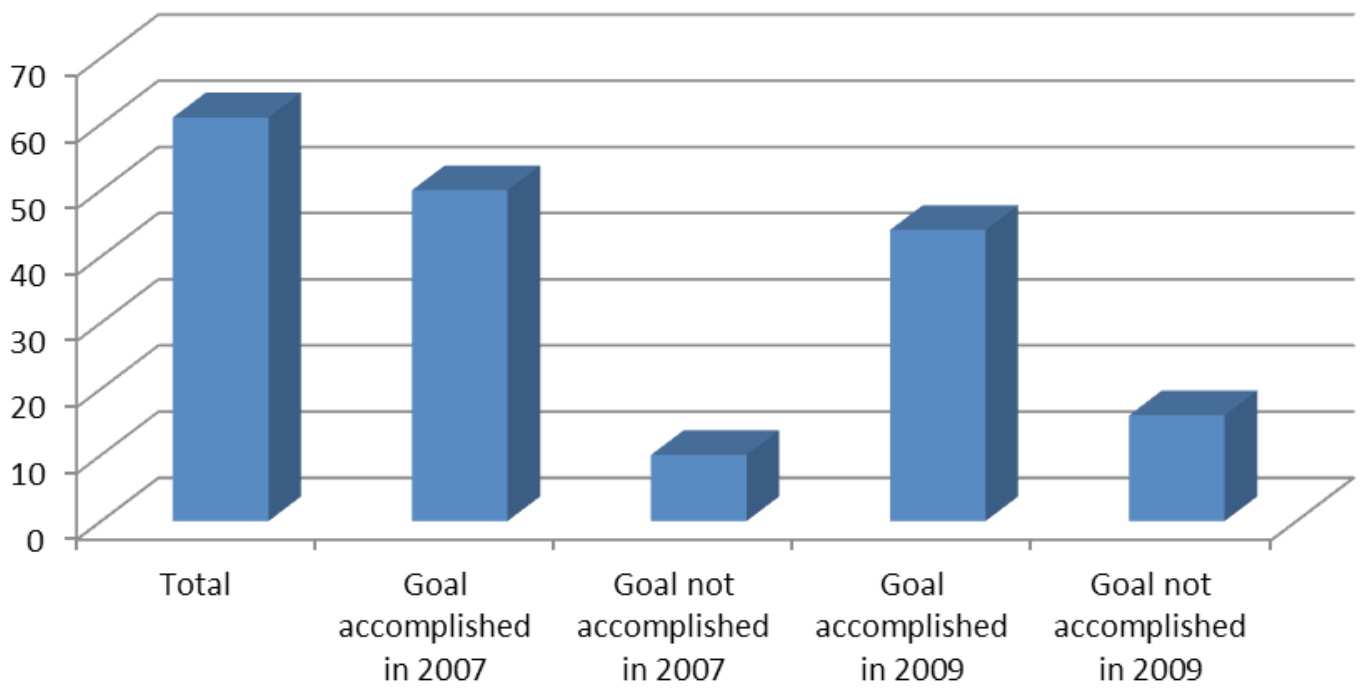

Figure 1: Years in which IDEB t goals were achieved.

Source: Data organized, based on the survey conducted by the IDEB (2007 and 2009) from SEED/PR/Brazil.

Only ten schools (Table 2) failed to achieve the goal set for 2007 and in 2009 that number increased to sixteen. However, one cannot help but notice that the grades in general, schools that have teachers and educators involved in the continuing education process considerably increased (Figure 2), which means the PDE-PR has been causing a difference in the results of IDEB.

The maximum difference of grade between the results of 2007 and 2009 reached 1.3 points, a school that had two teachers participating in the PDE-PR. Another school got 1.0 point 
Romilda Teodora ENS, Gisele Rietow BERTOTTI, Rudimar Gomes BERTOTTI. Initial Results of a Differentiate Program of Teachers Continuing Formation in Brazil: The PDE/Parana

difference had an educator and one teacher participants. Another institution had the grade of 0.9 points and had three participating teachers. Two schools reached 0.8 differences and had a teacher and educator participants, which confirms the hypothesis mentioned above about the influence that PDE-PR may cause in the grades obtained in IDEB.

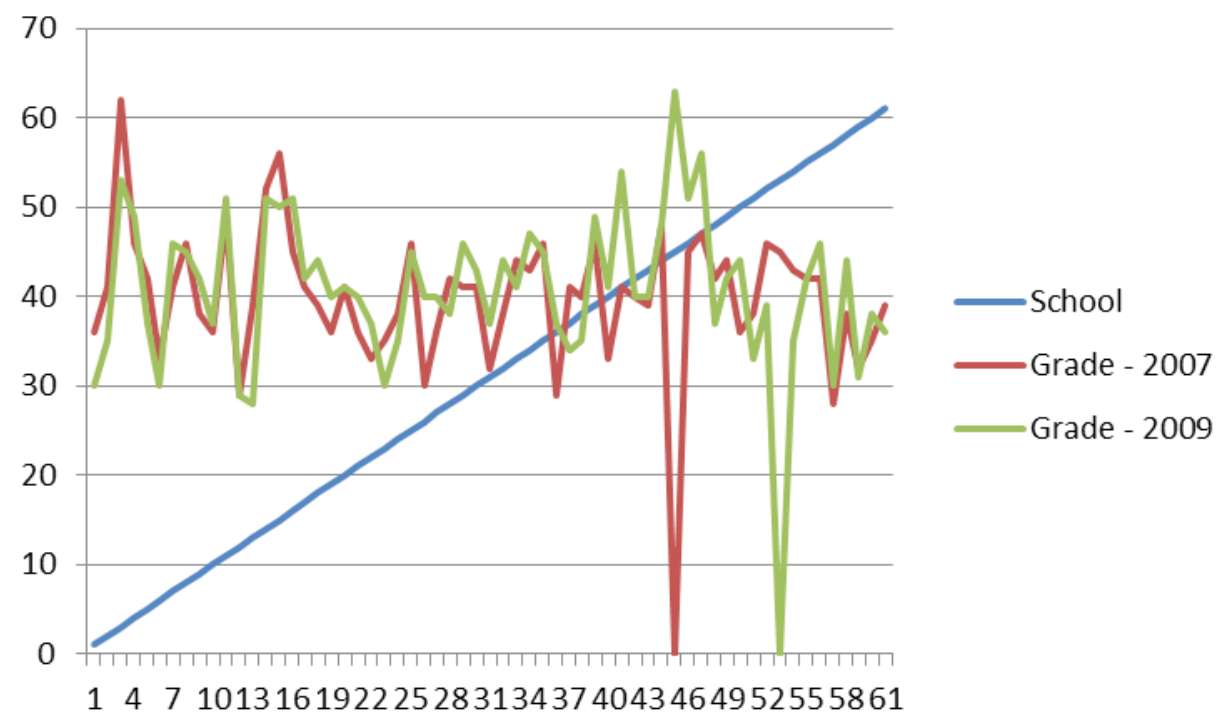

Figure 2: Movement of IDEB grades in 2006/2007 in state schools in Curitiba / PR.

Source: Data organized, based on the survey conducted by the SEED / PR and IDEB.

Thus, one can observe a relationship between the number of participating teachers and educators and the difference in the result obtained, indicating that participation in continuing education PDE-PR program influences in the grade of IDEB.

It is worth noting that some schools already reached an average 6.0, established as a national goal for 2021, which makes it even more motivating further develop research that attempts to investigate which factors influence the grade of IDEB, increasing the number of data analyzed, since here it was made only an initial study that has shown relevant results.

However, we cannot help but analyse the conflicting issues that permeate both programs. The IDEB is causing a discomfort among schools, mainly because their results are not being used for school improvement but to establish rankings. The training program also causes a discomfort among teachers who already have courses stricto sensu postgraduate (Masters or PhD) and are not considered eligible to entry into the last level of the teaching profession. They are required to participate in the PDE-PR, with points awarded for the entrance. Even if it is recognized that, in relation to the forming process, as an innovative proposal.

\section{Conclusions}

During the 1990s, educational reforms promoted were marked by decentralization practices, control and privatization. According to Oliveira (2009), "programs and projects implemented in the context of this law made the administrative, financial and pedagogical competence of school management "(p. 256).

Such decentralization policies culminated in the practice of an evaluation system coming from outside, instituting a culture of competition in public and private schools in Brazil.

In 2003, with a new proposal, compensatory policies became predominant, through a system of grants and understanding education as an inalienable right, making a priority the expansion of the educational system and the elevation of their levels of quality, according to Cunha (2009). 
Romilda Teodora ENS, Gisele Rietow BERTOTTI, Rudimar Gomes BERTOTTI. Initial Results of a Differentiate Program of Teachers Continuing Formation in Brazil: The PDE/Parana

PRLEMS

OF EDUCATION

IN THE $21^{\text {st }}$ CENTURY

Volume 60, 2014

Along with this proposal, fragmentation of educational policies continued predominating, marked by a multiplicity of projects and regulations. To answer the criticism regarding these aspects, the Education Development Plan (PDE) was launched by the federal government covering over forty programs for evaluating student performance from the children's education to the higher education, with emphasis in the basic public school, to improve the evaluation of the students (Oliveira, 2009).

Among these programs, appeared in 2007 the Index of Basic Education Development (IDEB). Even with the creation of a whole system of review by the Brazilian federal government, educational assessment has not lost the predominant influence of reviews coming from outside, because IDEB has several logical connections with external monitoring, as shown by Fernandes (2010).

The author also exposes some criticisms about the assessment program. The first is about the goal of 6.0 grade set for 2021, she argues that the best and worst schools tend to hold their position and stipulate a grade equal to both in a given period of time demonstrates the lack of induction of equity and disregards local developments (Fernandes, 2010).

Besides the aspects mentioned above, to think about the evaluation of education, it is necessary to remember that the fact of basing education on tests may cause the decrease in their quality, despite the increase in the index (Silva, 2011). Many teachers tend to prepare their students for the tests, as well as some institutions tend to avoid as much to promote the disapproval so there is no decline in the index and the transfer of resources is not diminished.

Considering only the performance and census research of a group of students at a given grade in the subjects of Mathematics and Portuguese, disregarding the assessment of the professionals involved and the policies underlying the process can also be considered fragile aspects of the use of IDEB.

However, when considering the teacher training, one realizes that there is a consensus among authors that discuss the topic that must take into consideration the formation of a critical professional, knowledgeable and participant definitions of public policies that underlie their practice and not merely a reproductive system (Gatti, Barreto, 2009; Silva, 2011; Freire, 2012). Thus, understanding the IDEB and reflect on the influence of continuing education in their results contribute to a better understanding of two public-reaching policies in Brazil, one of the state, another federal.

It is also necessary to emphasize that the fundamental and continuing education for faculty professional development and its results can be seen in part of institutional assessment instruments (Sordi, 2005). Thus, assessing the impacts of (PDE-PR) Teaching Development Program becomes relevant for innovation methodological character, integration between university and school and encouraging research and development of academic productions.

Finally, it is emphasized that this study developed here has an initial character; more data will be fetched and added in later studies to the complex dimension of the impacts of teacher training PDE-PR program are analyzed, and to some extent analyzed. In this sense, raise contributions for the resizing of public policies on teacher education and teaching. It is noteworthy also that this proposed training, continuing up to the present moment, it is proposed to trace aspects that enable the design of improved prospects for both continuing education and enhancement of teacher for their bond to the teaching career plan of Parana State in improving the basic education of Parana.

However, it is important to notice that $\mathrm{t}$ the analysis performed until now indicate per passed routes are opposed to the effectiveness of democratic spaces in the schools. Thus, at the same they emphasize the appreciation of the teacher in the legal documents, establish the formative process as the only way to access the last level of the teaching career, emphasizing mainly work time, in the entrance exam to the program, and seeking to achieve the established goals to improve the public schools which substantiate in the IDEB's grade, once the tests do not consider the specific characteristics of knowledge in different contexts, to what extension they can be considered a kind of measurement of school quality. 


\section{References}

Apple, M., Au, W., \& Gandin, L. A. (2011). Educação Crítica: Análise internacional. (Critical Education: an international analysis (Vinícius Ferreira Trad. and Luís Armando Gandin Technical Review). Porto Alegre: Artmed.

Brazil Test and SAEB: frequently asked questions. Institute of National Studies and Research Anísio Teixeira (INEP). (2007). Brazil. Retrieved from http://provabrasil.inep.gov.br/perguntas-frequentes.

Complementary Law 103, March 15th, 2004. Diário Oficial do Estado do Paraná, Curitiba, PR, n. 6687. Paraná. Retrieved from http://www.legislacao.pr.gov.br/legislacao/pesquisarAto.do?action=exibi r\&codAto $=7470 \&$ indice $=1 \&$ totalRegistros $=1$.

Complementary Law 130, July 14 ${ }^{\text {th }}, 2010$. Diário Oficial do Estado do Paraná, Curitiba, PR, n. 8262, $14^{\text {th }}$ Jul. Paraná. Retrieved from http://www.legislacao.pr.gov.br/legislacao/pesquisarAto.do?action=e xibir\&codAto $=56184 \&$ indice $=1 \&$ totalRegistros $=2$.

Cunha, L. A. (2009). As políticas educacionais entre o presidencialismo imperial e o presidencialismo de coalizão (Educational policies between imperial presidentialism and presidential coalition). In E. B. Ferreira \&D. A. Oliveira (Orgs.). Crise da escola e politicas educativas (Crisis at school and educational policies). (pp. 121-140). Belo Horizonte: Autêntica.

Decree n. 4.482, March 14 ${ }^{\text {th }}$ 2005. Diário Oficial do Estado do Paraná, n. 6933. Paraná. Retrieved from http://www.legislacao.pr.gov.br/legislacao/listarAtosAno.do?action=iniciarProcesso\&tipoAto=1 $1 \&$ orgaoUnidade $=1100 \&$ retiraLista $=$ true $\&$ site $=1$

Decree n. 6.094/2007, from April $24^{\text {th }}$. Diário Oficial da União, April 25 ${ }^{\text {th }} 2007$. Brazil. Retrieved from http://www.planalto.gov.br/ccivil_03/_ato2007-2010/2007/decreto/d6094.htm.

Documento síntese (Synthesis document). (2014). Programa de Desenvolvimento Educacional - PDE (Program of educational development- PDE). Secretaria de Estado da Educação. (State department of education). Coordenação Estadual do Paraná (State coordination of Parana). Curitiba. Retrieved from http://www.gestaoescolar.diaadia.pr.gov.br/modules/conteudo/conteudo.php?conteudo=500

Ens, R. T., \& Gisi, M. L. (2011). Políticas Educacionais no Brasil e a Formação de Professores (Education Policy in Brazil and Teacher Formation). In: Ens, R. T. \& Behrens, M. A. (Orgs.). Politicas de formação do professor: caminhos e perspectivas (Policies for teacher education: pathways and prospects). (pp. 25-49). Curitiba: Champagnat.

Fernandes, C. F. R. (2010). O IDEB e a prova Brasil na gestão das escolas municipais de Vitoria (The IDEB and Brazil Test in the management of public schools in Vitoria), ES. In $33^{\text {rd }}$ Reunião Anual da Associação Nacional de Pós-Graduação e Pesquisa em Educação (Annual Meeting of the National Association of Graduate Studies and Research in Education ).(ANPED). GT05. Retrieved from http://www.anped.org.br/33encontro/app/webroot/files/file/Trabalhos\%20em\%20PDF/ GT05-6889--Int.pdf.

Fernandes, R. (2007). Índice de desenvolvimento da educação básica (Index of basic education development). INEP. Brazil. Retrieved from http://biblioteca.claretiano.edu.br/phl8/pdf/ideb.pdf.

Foucault, M. (2008). O nascimento da biopolitica: Curso dado no Collège de France (The birth of biopolitics: Course given at the Collège de France). (1978-1979). Class on April $4^{\text {th }}$ of 1979. São Paulo: Martins Fontes.

Freire, P. (2012). Educação e atualidade brasileira (Education and Brazilian present). $3^{\text {rd }}$ Ed., São Paulo: Cortez. (Originally published in 1959).

Garcia, J. (2008). Indisciplina na escola: Questões sobre mudança de paradigma (Indiscipline in schools: Issues in paradigm shift). Contrapontos, Itajaí, 8 (3), 367-380. Retrieved from http://siaiweb06. univali.br/seer/index.php/rc.

Gatti, B. A. (Coord.) \& Barreto, E. S. S. (2009). Professores do Brasil: Impasses e desafios (Teachers of Brazil: Challenges and Impasses. Brasília: UNESCO.

Gentili, P. (2004). Três teses sobre a relação trabalho e educação em tempos neoliberais (Three theses on the relationship between work and education in neoliberal times). In: Lombardi, J. C. Saviani, D. Sanfelice, J. L. (Orgs.). Capitalismo, trabalho e educação (Capitalism, work and education). (pp.45 - 59). 2. Ed. rev. Campinas, SP: Autores Associados, HISTEDBR.

IDEB. Education: how is IDEB calculated. (2007). Alagoas. Brazil. Retrieved from http://www.educacao.al.gov.br/sistema-estadual-de-educacao/indice-de-desenvolvimento-da-educacao-basicaideb/como-o-ideb-e-calculado .

IDEB website (2014). Brasil. Retrieved from http://anterior.portalideb.com.br/\#\{“municipio_id”:"41069 02","rede":"estadual"? 
Romilda Teodora ENS, Gisele Rietow BERTOTTI, Rudimar Gomes BERTOTTI. Initial Results of a Differentiate Program of Teachers Continuing Formation in Brazil: The PDE/Parana

PROBLEMS

OF EDUCATION

IN THE $21^{\text {st }}$ CENTURY

Volume 60, 2014

Lara, A. M. B. \& Maroneze, L. F. Z. (2012). A política de pessoal da educação e os desafios da precarização do trabalho dos professores na rede estadual de educação básica do Paraná (The personnel policy of education and the challenges of precarious work of teachers of Basic Education in the state of Paraná) (1995-2002). In Politicas educacionais: Um exame das proposições e reformas educacionais. (Educational policy: An examination of the propositions and educational reforms). (pp.117 - 146). Paraná: Editora Unioeste.

Law Project n. 8.035/2010. PNE (Still in analysis at the National Congress). Ministry of education. Brazil. Retrieved from < http://bd.camara.gov.br/bd/handle/bdcamara/5826//wwww.mec.gov.br>.

Munhoz, M., \& Kovaliczn, R. A. (2012). A formação continuada dos professores da rede pública de ensino do estado do Paraná, nos governos Lerner e Requião: semelhanças e diferenças perceptíveis. (The continuing formation of teachers in the public schools of the state of Paraná, in governments Lerner and Requiao: similarities and notable differences) Paraná. In Simpósio de educação da XX semana de Pedagogia. (Education Symposium on the twentieth week of Pedagogy). Retrieved from http://www.unioeste.br/cursos/cascavel/pedagogia/eventos/2008/1/Artigo\%2016.pdf.

Oliveira, J. F. (2009). A função social da educação e da escola publica: tensões, desafios e perspectivas (The social function of education and public school: tensions, challenges and prospects) In: Ferreira, E. B.; Oliveira, D. A. (Orgs.).Crise da escola e politicas educativas. (Crisis at school and educational policies). (pp. 237-252). Belo Horizonte: Autêntica.

PDE. (2007). Ministry of education. Brazil. Retrieved from http://portal.mec.gov.br/arquivos/livro/ and/ or http://www.dominiopublico.gov.br/download/texto/me004370.pdf.

Silva, M. A. (2011). A questão docente nas políticas públicas (The teacher question in public policy). In: Cunha, C.; Sousa, J. V; Silva, M. A. Políticas públicas de educação na América Latina: Lições aprendidas e desafios. (Public education policies in Latin America: Lessons learned and challenges) (pp. 325 - 354). Campinas, SP: Autores Associados.

Sordi, M. R. L. (2005). Avaliacao da qualidade do trabalho docente: do auto-engano ao auto-conhecimento.( Evaluation of the quality of teaching: from self-deceiving to self-knowledge In: Romanovski, J. P.; Martins, P. L. O.; Junqueira, S. R. A. Conhecimento local e conhecimento universal: Formação docente, aprendizado e ensino. (Local knowledge and universal knowledge: teacher formation, learning and teaching) (pp. 121 - 136). Curitiba: Champagnat.

Wachowicz, L. A. (2012). Uma inversão didática nos cursos de pós-graduação. (Didactic inversion in postgraduate courses). Diálogo Educacional, Curitiba, PR, 9(26), 29- 45. Retrieved from http:// www2.pucpr.br/reol/index.php/DIALOGO?dd1=154.

Advised by Saleh A. Alabdulkareem, King Saud University, Saudi Arabia

Received: May 05, 2014

Accepted: June 26, 2014

Romilda Teodora Ens

PhD., Professor, Advisor at PUCPR, Imaculada Conceicao Street, 1155.

Prado Velho. Curitiba/Parana/Brazil.

E-mail: romilda.ens@gmail.com

Gisele Rietow Bertotti

Master Degree Student at PUCPR, Imaculada Conceicao Street, 1155.

Prado Velho. Curitiba/Parana/Brazil.

E-mail: giselertw@gmail.com

Rudimar Gomes Bertotti

Master Degree Student at UFPR, XV de Novembro Street, 1299. City Cen-

tre. Curitiba/Parana/Brazil.

E-mail: rudigbertotti@gmail.com 